\title{
A Changing of Masculinity Hegemony of the Beast Character in "Beauty and the Beast" Stories
}

\author{
Wahju Kusumajanti \\ English Department Faculty of Arts and Humanities \\ Universitas Islam Negeri Surabaya \\ Indonesia \\ wahjukusumajanti@uinsby.ac.id
}

\author{
Ovi Winda Vristian \\ English Department Faculty of Arts and Humanities \\ Universitas Islam Negeri Surabaya \\ Indonesia \\ oviwindavrist@gmail.com
}

\author{
Zulidyana Dwi Rusnalasari \\ English Department Faculty of Arts and Humanties \\ Universitas Islam Negeri Surabaya \\ Indonesia \\ zulidyana@gmail.com
}

\begin{abstract}
This research analyzes the three versions of Beauty and the Beast, they are: a short story by GabrielleSuzanne Barbot de Villeneuve in 1740, the animation version by Disney in 1991, and the live-action of by Disney in 2017. This research focuses on the lead male character, the Beast. This research uses new criticism and masculinity as the theory to find out the characterization and the hegemonic masculinity of the Beast. The source of data obtained by analyzing the hegemonic character of Beast in these three versions, compare and make meaning from those comparisons. This study found that the characteristics of Beast are : emotional, rude, badtempered, and well-educated. While, the masculinity sides of Beast are: wealthy, handsome, showing violence and domesticity. Those characteristics change and different in each version. The comparison shows that masculinity standards are changing following the trends and cultural changing.
\end{abstract}

Keywords: new criticism, characteristics, masculinity, hegemony masculinity

\section{INTRODUCTION}

Nowadays, the roles of woman and man have been switching, which are not only women that can do the men's role, but the men also can do the women's role. In some societies, the men's role usually they just go to work, they can get a good education, they can go to school, for some of the men they have to go to the war if they are a soldier, and some of the men usually do not care about the household chores or taking care of their children. On the other hand, there are also some of the men can do women's role. For example, the men can do the household chores, while they also go to work. Men nowadays also can cook or take care of their children if they have children.

Men were not born with the masculinity in their own even though he was born as a male, because masculinity is a category of how to be men based on cultural acceptance and social construction[1]. The masculinity can be the standards for the men to make them can be men. The men who want to be men, they must have the categories of masculinity to make them become men. The men who have masculinity in their own, they will show it through their behavior, their actions, or through how the other people point of view. Masculinity not only can be found in the real world, but, masculinity also can be found in the literary work, and it can be seen in the male character such as superhero, the prince, a thief, or even a monster.[2]

Every literary work always had the characters inside the story. Some of the characters in literary work there is a male and female character. The characters in literary work have the function to make the story feels alive.[3] The literary work also has an issue that the author wants to show to the reader. Masculinity becomes an issue in literary work. Literary work itself is the reflection of a society which is represented by the author at the time when the literary work was written by the author. The author reflects the social condition of society through the stories, the movies, and poetry, etc. The literary work can also be famous because of the characters, issue, or the event in the story. In this research, the researcher used one of the famous short stories Beauty and the Beast by Gabrielle-Suzanne Barbot de Villeneuve. Beauty and the Beast already written by Madame de Villeneuve in 1741. Beauty and the Beast was adopted by Disney. Disney made a movie of Beauty and the Beast in the animated version in 1991 and the liveaction version in 2017

We expect that this study will help the readers to get more knowledge or information about the changing masculinity, and become one of the comprehensive gender studies. This study will also contribute to the knowledge and references for literature student as well as the people that interest in literary studies. 
In this study, we use close reading as the method because, it can help the researcher to analyze one of the formal elements and that is character and characterization of the Beast. We found that at the beginning of the text, the author did not describe Beast as a handsome prince, but showed him as a frightful monster who lived in the castle in the far-off land. While, in both movies, at first, they described Beast as the prince, and then Beast changed into a monster because Beast was cursed by the enchantress. The enchantress cursed Beast because she hated Beast and his attitude. Then, the curse was broken by the other character, and it turned the Beast back being a human again.

In this chapter, we wanted to put the ideas or theory about new criticism and masculinity as the theory used to analyze this research. There are some ideas of new criticism. New criticism is the Anglo-American and the kind of formalism that appeared in the early twentieth century and new criticism dominated the teaching and the scholarship in the early 1960s, and new criticism is the theory that it does not have any relation with the social world include the author who wrote or created the story. New criticism is the practice that strongly favors for poetic texts, in large part because the poetic text shows to a greater level of the ambiguity, paradox and the irony considered by the new critics as the crucial elements from the poetic form. [4]. So that, the researcher uses new criticism as the theory for this research because new criticism theory can help the researcher to explain the formal elements as well as the character and characterization of "the Beast" in the short story of Beauty and the Beast by Gabrielle-Suzanne Barbot de Villeneuve, "the Beast" in the Beauty and the Beast in animation version by Disney in 1991, also "the Beast" in the Beauty and the Beast in live-action version by Disney in 2017.

As the main point, the character is the part of formal elements, and there are some ideas about the definition of character. Character is the one or the ones that are involved in the literary works [5]. The characters are the people who present in the dramatic or narrative literary works who construed by the readers or audiences as being blessed with the unique moral, intellectual, and the emotional qualities by interpreting from what the people say or person say and also through their extraordinary ways of saying the dialogue and do their action. [3]. From the statement above, it has meaning that, the characters are a people who played in the dramatic arts or narrative literary works, and the characters can also interpret the moral, intellectual, and emotions to the reader or the audience through their action or their dialogue when they played the drama, movie, etc. So that, the reader or the audience can feel what each characters feel also, or the reader or the audience can be emotional because the characters show their emotions through their dialogue, their action, their expression, etc.

There are several ideas about masculinity itself. Before going further, we need to mention the differences between sex and gender. Sex is the biological defined while gender is the social construct and was made by the society. Sex is the given from God to define, which is the male and which is the female. While, the gender can be seen through the way of how people act or how their behavior in public, a set of social pressure, and then gender also can be the identity of someone, and the way of someone interacts with each other, and so on. [6]

On the other hand, as one of the gender studies, masculinity is not practicable because masculinity itself is the social construct and was created when the men have a relation with the others in the interaction. But here, there is no single masculinity. Means that, there are several types of masculinity and it called as the multiples masculinity. There are four types of masculinity: hegemony masculinity, subordination masculinity, complicity masculinity, and the last marginalization masculinity. The multiples masculinity operates within the power differential, the dominant of the other men, opening about violence, aggression, and so forth. [7].

Hegemony masculinity is the concept of men who have power in society, and he could take control, or he could be more dominance of the other men. A man who wants to have the hegemonic masculinity side they must have several categories, they are: showing about violence, showing about the domesticity, some of them can be misogyny, and then heterosexual. So that, the stressing in the hegemonic masculinity and it makes hegemonic masculinity different from the other types of masculinity is hegemonic masculinity is not in the control of the women side only, but the hegemony masculinity more interest to be a person who more dominance than the other men or the men in the society. [1]

\section{DATA ANALYSIS}

In three versions of Beauty and the Beast, Beast included in the round character, because he has several characteristics and some behaviors. They are emotional, gentle, rude, bad temper, and well-educated. To analyze the characteristics of the Beast, we start it from the text, the animation version, and the last the live-action version.

\section{A. Beast as an emotional person}

In these three versions Beast was characterized as an emotional person. In the text, he described with several emotions, such as: sad and happy. The most particular one was, when Beast showed his emotion when he was rejected by Beauty. In her dreams, Beauty had dreams about marrying handsome young prince. More over, she had assume that Beast as the creature that capture her father, she has no feeling (at the beginning) about the Beast although they were living together. Beauty never thought about the Beast, and because of the dream. Beauty did not want to marry the Beast, and it makes the Beast sad. Because he expect Beauty too much( p. 19)

While, in the animation version, Beast showed his emotion through his expression. The first is regret. Beast looked like he regrets and quite sad after he saw Belle was crying in jail. Beast looks sad and regrets because he let Belle's father go while Belle did not say goodbye to her 
father. Beast let Maurice free because Belle wants to be Beast prisoner to replace her father. (minutes. 25:20). He also feel sad and hopeless when he sat down in the room in the castle, talking to Cogsworth that he had let Belle free. The reason why the Beast let Belle free because he did not want to make Belle sad, Belle saw her father through the magic mirror, and she saw that her father in danger. Actually, Beast let Belle go because he loves Belle.( minutes 01:08:07 ). After the scene, Beast thought that, if Belle loves him back, she will definitely back to his castle. This expectation make him hopeless and sad. Because while he was waiting, he has to deal with several problems. He looks sad and hopeless, represented in his behavior and expression.

The third emotion is hopeless, and it was shown when Beast's castle was attacked by the villagers, Gaston, and Le Fou. He was sitting down in the room in his castle. He seems to doing nothing, and let the villager in. (minutes 01:17:23).

On the other hand, in the newest version in 2017 , We found three scenes when Beast shows his emotion through his expression. First, Beast looks happy and smiling when he was playing snowball with Belle in the garden. At first, Belle throw the snowball to Beast, and he trhow the snowball back to Belle, in a bigger size, until she fell, then he laugh. (minutes 01:12:10). The other emotion showed when Beast admitted that he regret to called Belle's father "a thief". When Beast brought Belle to Paris, the place where she was born and the place where her mom died. Beast understand why Maurice pick the rose, he then found out the reason why Maurice loves Belle so much, and Maurice did not want to lose Belle as he loses Belle's mother. (minutes 01:19:32). The third scene showed, as almost the same with the animated version. The scene when Belle left the castle, and he just let her free. When Cogsworth asked Beast why he let Belle go, the answer is because Beast loves Belle, and it has to let Belle free because he can not stand to seeing Belle worry.( minutes 01:30:01)

\section{B. Beast as a gentle person}

In the text, Beauty told her father about Beast's behavior and how the way Beast treated Beauty when she was lived in the castle, and she said that even though Beast is the frightful creature, but he is a gentle person, and it makes Beauty's father thoughts that the Beast deserves her love and he thoughts that Beast does not terrify creature as he thoughts before. As the prince in her dreams said, do not trust the appearance; it was true. Through the dialogue between other characters and through the other characters reaction to Beast, it shows that Beast has the gentle behavior although it is a monster and he is not a handsome young prince as a prince in her dreams. ( p. 22 )

In the animation version, Beast is a gentle person can be seen in the first scenes when Belle say thank you to Beast because Beast saved Belle's life from the wolves. Beast said "You're welcome " to the Belle with the gentle voice and he does not shout out to the Belle as before. It shows that gentle side of the Beast can be seen through the way it communicates with the Belle. (minutes 00:50:15). Next scenes, Beast gave Belle a surprise, and when he talks to Belle, he uses his gentle voice, and his behavior shows that he has a gentle side when he shows the library inside the castle to the Belle. It shows that the Beast's gentle side can be seen through his behavior to Belle, and through the way, he talks to Belle. ( minutes 00:52:46 ). Third scenes, Beast asked Belle to read the Romeo and Juliet story by Shakespeare for it. When it asked Belle to read the story, it used the gentle voice to Belle, and it did not snap out to the Belle when it asked Belle to read the story for him. It shows that the gentle side of the Beast can be seen through the dialogues between Belle and Beast.( minutes 01:00:43)

In the live-action version, in the first scene that shows Beast was a gentle person when Beast used his gentle voice when he said that he wants to give his library in his castle to the Belle because he knows that Belle's hobby is reading. ( minutes 01:09:45 ). Second, Beast talks to Belle in the garden of the Beast's castle. Belle told Beast that the villagers described her as a funny girl. But the Beast answered the comments from the villager about Belle with his gentle voice, and it said that the villager in the Belle's villages is a terrible people. ( minutes 01:15:43 ). Third, when Belle came back to her village, she came back and left the Beast because she knew that her father in danger. When Belle came back, the villager will send her father to the hospital because the villager thought that Maurice is a crazy person because they thought that Maurice was lying to them about the Beast inside the castle. When Belle came, and she brought the magic mirror, she showed the Beast to the villager. But Belle told them that Beast is a gentle and kind person, so they do not need to be afraid of Beast. ( minutes 01:35:50)

\section{Beast as a rude person}

The short story of Beauty and the Beast by Gabrielle-Suzanne Barbot de Villeneuve did not shows or describe that Beast here is a rude person.

While, in animation version, Beast as a rude person shows when Beast drag Maurice to get out from his castle and sent Maurice back to the village even though Maurice begged to Beast to allow him to say goodbye to his daughter. Maurice was free because Belle already replaced to be Beast's prisoner. ( minutes 00:24:38 ). On the other hand, in live-action Beast as a rude person in these versions when Beast dragged Maurice to get out from his castle and sent him back to the village where he lived. But here, the Beast let Maurice say goodbye to his daughter before he back to the village. ( minutes 00:31:30).

\section{Beast as a bad-tempered person}

In the text version, Beast as a bad-tempered person here can be seen through the dialogue between Beast and the merchant, it shows that the Beast get mad to the merchant, and the merchant is a Beauty's father. The Beast 
For the masculinity side of Beast, in these three versions has the result, and the result is: Wealthy, Handsome, Showing about Violence, and Showing about the domesticity.

\section{A. Beast as a wealthy person}

In the text versions, Beast as a wealthy person can be seen through the dialogue between Beast, Beauty and the merchant, it shows that Beast give Beauty order to take her father into the next room and the Beast prepared two trunks to fill them as full as they can. The narrator in the story describes the presents that already prepared by the Beast to the merchant and Beauty's brothers and sisters. Beast is a rich person; it can be seen from the presents that described by the narrator, such as a luxurious dress, the jewels, and the gold. (p. 12 )

In the animation version, Disney also shows Beast as a wealthy person through the narrator, at the beginning of the movie, said, "Once upon a time, in the faraway land, a young prince living in the shining castle. Although he had everything his heart desire..." and at the beginning of the movie, the Beast is a human, he is a prince and wore the prince's clothes and wore a crown on his head. ( minutes 00:01:24).

The live-action version also shows Beast as a wealthy person through the narrator said that " Once upon a time in the hidden heart of France. A handsome young prince lived in a beautiful castle. Although he had everything his heart desired... and he invites the great person to come to his party in the castle". It shows that the Beast is a rich person can be seen through the clothes that he wear, and it can be seen through the luxury things inside his castle and when the party held, he sat down in the luxurious golden chair in the hall of his castle and when the party started he wearing curly hair, wearing a makeup in his party, and he wears luxurious clothes at the party.( 00:00:48).

\section{B. Beast as a handsome person}

Through the narrator description, it shows that Beauty finds that Beast was disappeared and its changes into a human again. When Beast being human again, he is a handsome prince, and it is not a monster again. It means that the narrator in the short story describes Beast when it turns to be human, as a handsome prince. ( p. 25 )

The animation versions by Disney, shows that Beast turns to be human again because Belle already breaks the cursed. Through the physical appearance of the Beast, he had a long hair the color is brown; he had blue eyes, his nose is pointed, his eyebrow is bold, his body makes him looks like he is a strong person. (minutes 01:23:08). Through the description, it can be seen that Beast's physical appearance was changing from a monster to be a handsome prince and not a frightful monster again. Beast being a handsome prince because another character already breaks the cursed and made Beast became human again and everybody in the castle being normal again, Beast is a found that the Beast was read some book about King Arthur (minutes 01:14:51). 
description, Beast wants to married with Beauty, and it can be proved that the Beast openings about domesticity

In the animation version, Beast who already became human again, married with the Belle in the hall in his castle. In this scene, he danced with the Belle, and he celebrated his wedding with the Belle, and he also invites all of the people to his castle to celebrate that the cursed was gone and they are human again. ( minutes 01:24:36 ). It means that Beast is not a misogyny person, because he still openings about the domesticity because he still wants to marry.

While in the live-action version, Beast married Belle after he transformed being human again, and he danced with Belle in the hall of his castle. The Beast invites the villager to his castle to celebrate his wedding and also to celebrate the cursed was gone and all of them being human again. In this movie, ( minutes 01:57:17 ). In this version, Disney also shows that Beast opening about the domesticity because he wants to marry Belle.

\section{CONCLUSION}

From the discussion above, it can be concluded that Beast portrayal is characterized as emotional, gentle bad-tempered, rude, and the last well-educated. In these three versions of Beauty and Beast, there are differences and similarities. First, to show the differences between three versions: Beast's rude characteristics. In the text, Beast does not have rude characteristics. But, in both movies, Beast has rude characteristics, and it shows when it dragged Maurice to leave the castle and sent him back to the village. The next is Beast's well-educated character. In the text, the author did not describe that Beast as a well-educated person vividly, because the author only shows that Beast has a library in the castle. In the animation version, Disney showed that Beast cannot read even he has a library in the castle, so Belle thaught him to read. While, in the live-action version, Disney shows that Beast as a well-educated person.

While the similarities in these three versions are: first, the emotional of Beast, in these three versions, it describes that Beast still has various emotions and can be an emotional person; sometimes, the emotions that the author shows in these versions is sad. In these three versions, Beast sad because Belle leave the castle and come back to her own home, and it makes Beast sad or hopeless, and it can be seen through its expression. The second is the gentle side of Beast, in these three versions, all of them shows that Beast had a gentle side. In the text, Beast's gentle personality depicted through the other character point of view. It showed when Beauty told her father that Beast is a gentle and kind person ( Villeneuve, p.22 ). While, in both movies, it can be seen through the Beast behavior, such as it danced with Belle and through the tone that Beast used to communicate with Belle, it shows when Beast wants to give Belle a surprise. Third, Bad-tempered, Beast in these three versions characterized as a bad temper person. In the text, it 
shows through the dialogue between Beast and another character, and it happens

when Beauty's father pick the rose from Beast castle without permission. (Villeneuve, p.6 ). While, in both movies, it can be seen through the Beast expression, and also through the other character reacts to the Beast, and it happens when Beast snap at Belle when she gets into the west wings, and she also disobeys Beast order to not get into the west wings.

From the discussion above, Beast had several masculinity sides, they are : wealth, handsome, showing violence and domesticity. In these three versions of Beauty and the Beast, there are differences and similarities. The difference here is about showing violence. In the text, Beast does not do any violence activity to every character in the story. But in both movies, Beast showed that he is violent. The first scene is Beast fight the wolves to protect and save Belle's life. Belle's trapped in the wolves place because she runaway from Beast's castle after Beast get mad at her because she disobeys Beast order to not get into the west wings

\section{REFERENCES}

[1] R. W. Connell, "RW Connell's" Masculinities": Reply," Gend. Soc., vol. 12, no. 4, pp. 474-477, 1998.

[2] B. W. Finklea, "Examining masculinities in Pixar's feature films: what it means to be a boy, whether human, fish, car, or toy," University of Alabama Libraries, 2014.

[3] M. H. Abrams and G. Harpham, A glossary of literary terms. Cengage Learning, 2011.

[4] G. Castle, The Blackwell guide to literary theory. John Wiley \& Sons, 2009.

[5] C. Duffy and H. J. Pettit, A dictionary of literary terms. University of Denver Press, 1952.

[6] J. Lorber, Paradoxes of gender. Yale University Press, 1994

[7] R. W. Connell, Masculinities. Polity, 2005.

[8] Villeneuve, Gabrielle-Suzanne Barbot de. 1740. Beauty and the Beast. 